\title{
Penolakan Pencatatan Perkawinan Oleh Kantor Dinas Kependudukan Dan Catatan Sipil Akibat Terbitnya Akta Pembatalan Perkawinan
}

\author{
Cynthia Kweenedy \\ Magister Kenotariatan, Fakultas Hukum Universitas Surabaya \\ Email: Cynthiakweenedy17@gmail.com
}

\begin{abstract}
The research takes the theme of the Rejection of Marriage Registration by the Office of Population and Civil Registration of the City of Mataram due to the issuance of Marriage Cancellation Certificate Number 1 dated 22 July 2017 which was made before a Notary, by discussing the issue of the strength of binding to the Marriage Cancellation deed Number 1 dated July 222017 and the responsibility of the notary, researched using a normative juridical research type with a statutory approach, a conceptual approach and a case approach, the following conclusions are obtained: Deed of Marriage Cancellation Number 1 dated July 22, 2017 made before a notary has no binding power, because the notary does not have the authority to make deeds cancellation of marriage, but the authority of other officials as meant by the provisions of Article 15 of the UUJN. The making of the marriage annulment deed makes the prospective wife whose request for marriage registration is rejected suffer both material and immaterial losses. For such losses, the notary can be responsible from a civil law perspective on the basis of having committed an unlawful act as referred to in Article 15 UUJN in conjunction with Article 1365 KUH Perdata.
\end{abstract}

Keywords: Rejection of marriage registration, Deed of Cancellation, Notary.

Abstrak. Penelitian mengambil tema Penolakan Pencatatan Perkawinan Oleh Kantor Dinas Kependudukan Dan Catatan Sipil Kota Mataram Akibat Terbitnya Akta Pembatalan Perkawinan Nomor 1 Tanggal 22 Juli 2017 Yang Dibuat Di Hadapan Notaris, dengan membahas permasalahan kekuatan mengikatnya akta Pembatalan Perkawinan Nomor 1 Tanggal 22 Juli 2017 dan tanggungjawab notaris, diteliti menggunakan tipe penelitian yuridis normatif dengan pendekatan peraturan perundang-undangan, pendekatan konsep dan pendekatan kasus diperoleh suatu kesimpulan sebagai berikut: Akta Pembatalan Perkawinan Nomor 1 Tanggal 22 Juli 2017 yang dibuat di hadapan notaris tidak mempunyai kekuatan mengikat, karena notaris tidak mempunyai wewenang membuat akta pembatalan perkawinan, melainkan wewenang pejabat lain sesuai dengan yang dimaksud oleh ketentuan Pasal 15 UUJN. Dibuatnya akta pembatalan perkawinan tersebut menjadikan calon istri yang permohonan pencatatan perkawinan ditolak menderita kerugian baik materiil maupun immateriil. Atas kerugian tersebuit notaris dapat bertanggung jawab dari segi hukum keperdataan atas dasar telah melakukan perbuatan melanggar hukum sebagaimana dimaksud oleh Pasal 15 UUJN juncto Pasal 1365 KUH Perdata.

Kata Kunci: Penolakan pencatatan perkawinan, Akta Pembatalan, Notaris.

\section{PENDAHULUAN}

Perkawinan adalah sah bilamana dilakukan menurut hukum masing-masing agamanya dan kepercayaannya dan di samping itu tiap-tiap perkawinan harus dicatat menurut peraturan perundang-undangan yang berlaku, sebagaimana Pasal 2 Undang-Undang Nomor 1 Tahun 1974 tentang Perkawinan sebagaimana telah diubah dengan UndangUndang Nomor 16 Tahun 2019 tentang
Perubahan Atas Undang-Undang Nomor 1 Tahun 1974 tentang Perkawinan (selanjutnya disebut UU Perkawinan). Pencatatan tiap-tiap perkawinan adalah sama halnya dengan pencatatan peristiwa-peristiwa penting dalam kehidupan seseorang, misalnya kelahiran, kematian yang dinyatakan dalam surat-surat keterangan, suatu akte yang juga dimuat dalam daftar pencatatan (Mahkamah Konstitusi, 2010). 
Sebuah perkawinan yang diikuti seorang laki-laki (X) dengan seorang perempuan (Y), dilangsungkan melalui rangkaian upacara perkawinan menurut adat/agama. Namun ketika Y akan mencatatkan perkawinannya di Kantor Dinas Kependudukan Dan Catatan Sipil Kota Mataram, permohonan pencatatannya ditolak. Penolakan pencatatan dengan alasan adanya akta dibuat di hadapan Notaris Huznal Faizah Alyaminy yang isinya Pembatalan Perkawinan Nomor 1 Tanggal 22 Juli 2017.

Perkawinan yang akan dilangsungkan sesungguhnya dapat dicegah apabila ada pihak yang tidak memenuhi syarat-syarat untuk melangsungkan perkawinan sebagaimana dimaksud Pasal 13 UU Perkawinan. Berdasarkan Pasal 17 ayat (1) UU Perkawinan, pencegahan perkawinan diajukan kepada Pengadilan dalam daerah hukum tempat perkawinan akan dilangsungkan.

Notaris adalah pejabat umum yang berwenang untuk membuat Akta otentik sepanjang pembuatan Akta itu tidak dikecualikan kepada pejabat lain yang ditetapkan oleh undang-undang, sebagaimana Pasal 1 angka 1 juncto Pasal 15 ayat (1) Undang-Undang Nomor 30 Tahun 2004 Tentang Jabatan Notaris sebagaimana telah diubah dengan Undang-Undang Nomor 2 Tahun 2014 Tentang Perubahan Atas UndangUndang Nomor 30 Tahun 2004 Tentang Jabatan Notaris (selanjutnya disebut UUJN).

Notaris sebagai pejabat umum yang mempunyai wewenang membuat akta otentik, selain pejabat umum diakui adanya pejabat lain yang juga mempunyai wewenang membuat akta otentik, kewenangannya ditetapkan oleh undang-undang. Notaris Huznal Faizah Alyaminy, membuat akta Pembatalan Perkawinan Nomor 1 Tanggal 22 Juli 2017, dijadikan alasan oleh pejabat Kantor Dinas Kependudukan Dan Catatan Sipil Kota Mataram menolak ketika calon istri mencatatkan perkawinannya. Hal yang dipermasalahkan adalah kekuatan mengikatnya akta Pembatalan Perkawinan Nomor 1 Tanggal 22 Juli 2017 dan tanggung jawab notaris yang membuat akta dimaksud.

\section{METODE}

Tipe penelitian yang digunakan adalah penelitian hukum bersifat yuridis normatif, merupakan penelitian hukum melalui pendekatan masalah dengan melihat, menelaah dan mengintrepretasikan hal-hal yang bersifat teoritis yang menyangkut asas-asas hukum berupa konsepsi, peraturan perundangundangan, dan sistem hukum yang berkaitan.

Pendekatan-pendekatan yang digunakan adalah pendekatan undang-undang (statute approach), pendekatan konseptual (conceptual approach) dan Pendekatan kasus (case study) (Marzuki, 2009). Pendekatan undang-undang (statute approach) dilakukan dengan menelaah semua undang-undang yang bersangkut paut dengan isu hukum yang sedang ditangani. Pendekatan konseptual beranjak dari pandangan dan doktrin-doktrin yang berkembang dalam isu hukum, kasus dilakukan penelitian yang menempatkan sesuatu atau objek yang diteliti sebagai kasus pembatalan perkawinan yang dibuat dalam bentuk akta yang dibuat di hadapan notaris. Kasus tersebut telah diperiksa dan diputus dan putusan mana telah mempunyai kekuatan hukum tetap, yakni Putusan Pengadilan Negeri Mataram Nomor 264/PDT.G/2017/PN Mtr.

Bahan hukum yang digunakan dalam penulisan ini adalah bahan hukum primer dan bahan hukum sekunder. Bahan hukum primer merupakan bahan hukum yang bersifat autoratif, artinya mempunyai otoritas, mengikat dan mutlak dipergunakan berupa Perundang-Undangan lain yang berkaitan masalah yang sedang dibahas, antara lain Undang-Undang Hukum Perdata. Bahan Hukum Sekunder merupakan bahan hukum yang digunakan sebagai penunjang untuk memperkuat atau sifatnya menjelaskan bahan hukum primer yang ada, sehingga dapat membantu dalam membahas serta menganalisis permasalahan yang sedang diteliti. Bahan hukum sekunder yang digunakan antara lain buku-buku hukum, kamus hukum, bahan-bahan perkuliahan, bahan hasil penelusuran di internet, karyakarya ilmiah yang berkaitan dengan isu hukum yang dibahas serta pendapat-pendapat para ahli 
hukum baik praktisi maupun akademisi (Marzuki, 2009).

\section{HASIL DAN PEMBAHASAN \\ Pencegahan dan Pembatalan Perkawinan}

Unsur-unsur dalam perkawinan menurut UU Perkawinan adalah:

1) ikatan lahir dan batin,

2) antara seorang pria dengan seorang wanita sebagai suami istri,

3) tujuan perkawinan membentuk keluarga atau rumah tangga yang bahagia dan kekal,

4) berdasarkan hukum agama yakni berdasarkan Ketuhanan Yang Maha Esa.

Sudah seharusnya ada ikatan lahir batin dalam perkawinan. Keduanya harus berkaitan secara erat agar perkawinan tidak rapuh. Ikatan lahir mengungkapkan adanya hubungan formal, sedangkan ikatan batin merupakan hubungan yang tidak formal. Ikatan lahir sebagai ikatan yang dapat dilihat, menunjukan adanya hubungan hukum antara suami dan istri, mengikat antara suami dan istri serta pihak ketiga, yang diwujudkan dalam akta perkawinan. Ikatan batin merupakan ikatan yang tidak nampak, suatu ikatan yang hanya dapat dirasakan oleh suami dan istri. Perkawinan membutuhkan ikatan lahir batin sebagai dasar utama pembentukan dan pembinaan keluarga bahagia dan kekal (Wantjik Saleh, 1976).

Antara seorang pria dengan seorang wanita sebagai suami istri. Perkawinan hanya dapat dilangsungkan oleh seorang pria dengan seorang wanita. Perkawinan hanya mengikat seorang pria dengan seorang wanita sebagai suami istri. Artinya UU Perkawinan pada hakikatnya menganut asas monogami dan melarang poligami. Kata poligami sendiri berasal dari yunani "polygamie", yaitu "poly" yang berarti banyak dan "gamie" yang berarti laki-laki. Jadi arti dari poligami adalah lakilaki yang beristri lebih dari satu orang wanita dalam satu ikatan perkawinan (Reza Fitria, 2015). Namun asas monogami tersebut tidak mutlak karena seorang suami diperkenankan beristri lebih dari seorang apabila dikehendaki oleh pihak-pihak yang bersangkutan dan adanya izin dari Pengadilan sesuai ketentuan Pasal 3 UU Perkawinan.
Tujuan perkawinan membentuk keluarga atau rumah tangga yang bahagia dan kekal. Keluarga dalam pengertian tujuan perkawinan adalah satu kesatuan terdiri atas ayah, ibu dan anak (anak-anak). Keluarga dibentuk dengan harapan memberikan kebahagiaan bagi anggota keluarga, dapat berlangsung untuk selama-lamanya, hanya dapat dipisahkan oleh kematian.

Sebagai negara yang berasaskan Pancasila dengan sila pertamanya adalah Ketuhanan Yang maha Esa, Indonesia memandang perkawinan sebagai hubungan yang erat sekali dengan agama/kerohanian, sehingga perkawinan bukan saja mempunyai unsur lahir/jasmani, tetapi unsur batin/rohani juga mempunyai peranan yang penting (Akhmad Munawar, 2015).

Berdasarkan Pasal 2 Peraturan Pemerintah Nomor 9 Tahun 1975 (selanjutnya disebut PP 9/1975), pencatatan perkawinan bagi yang beragama Islam dilakukan oleh Pegawai Pecatat Nikah Kantor Urusan Agama. Sedangkan pencatatan perkawinan bagi yang agamanya selain Islam dilakukan oleh Pencatat Perkawinan pada Kantor Catatan Sipil, sebagaimana Pasal 34 Undang-Undang Nomor 23 Tahun 2006 tentang Administrasi Kependudukan sebagaimana telah diubah dengan Undang-Undang Nomor 24 Tahun 2013 tentang Perubahan Atas Undang-Undang Nomor 23 Tahun 2006 tentang Administrasi Kependudukan (selanjutnya disebut UU Adminduk).

Sahnya perkawinan dan pencatatan perkawinan menurut Penjelasan Umum angka 4 huruf b UU Perkawinan tentang asas-asas atau prinsip-prinsip perkawinan menyatakan, "...bahwa suatu perkawinan adalah sah bilamana dilakukan menurut hukum masingmasing agamanya dan kepercayaannya itu; dan di samping itu tiap-tiap perkawinan harus dicatat menurut peraturan perundangundangan yang berlaku. Pencatatan tiap-tiap perkawinan adalah sama halnya dengan pencatatan peristiwa-peristiwa penting dalam kehidupan seseorang, misalnya kelahiran, kematian yang dinyatakan dalam surat-surat keterangan, suatu akte yang juga dimuat dalam daftar pencatatan" (Mahkamah Konstitusi, 
2010). Atas uji materi Pasal 2 UU Perkawinan, Mahkamah Konstitusi (selanjutnya disebut MK) dalam Putusan Nomor 46/PUUVIII/2010 berpendapat bahwa:

1. Pencatatan perkawinan bukanlah merupakan faktor yang menentukan sahnya perkawinan; dan

2. Pencatatan merupakan kewajiban administratif yang diwajibkan berdasarkan peraturan perundang-undangan.

Adapun faktor yang menentukan sahnya perkawinan menurut adalah syarat-syarat yang ditentukan oleh agama dari masing- masing pasangan calon mempelai. Diwajibkannya pencatatan perkawinan oleh negara melalui peraturan perundang-undangan merupakan kewajiban administratif. Menurut MK, makna pentingnya kewajiban administratif berupa pencatatan perkawinan tersebut dapat dilihat dari dua perspektif. Pertama, dari perspektif negara bahwa pencatatan dimaksud diwajibkan dalam rangka fungsi negara memberikan jaminan perlindungan, pemajuan, penegakan, dan pemenuhan hak asasi manusia yang merupakan tanggung jawab negara dan harus dilakukan sesuai dengan prinsip negara hukum yang demokratis yang diatur serta dituangkan dalam peraturan perundangundangan. Kedua, pencatatan secara administratif yang dilakukan oleh negara dimaksudkan agar perkawinan sebagai perbuatan hukum penting dalam kehidupan yang dilakukan oleh yang bersangkutan, yang berimplikasi hukum sangat luas, di kemudian hari dapat dibuktikan dengan bukti yang sempurna dengan suatu akta otentik, sehingga perlindungan dan pelayanan oleh negara terkait dengan hak-hak yang timbul dari suatu perkawinan dapat terselenggara secara efektif dan efisien. Uraian terkait dengan sahnya perkawinan dan pencatatan perkawinan merupakan satu kesatuan yang tidak terpisahkan, mengingat sah menurut hukum agamanya, degan dicatatnya perkawinan diberikan jaminan perlindungan, pemajuan, penegakan, dan pemenuhan hak asasi manusia yang merupakan tanggung jawab negara.

Terkait dengan perkawinan, UU Perkawinan mengatur mengenai pencegahan perkawinan dan pembatalan perkawinan.
Pencegahan perkawinan diatur dalam Bab III UU Perkawinan tentang Pencegahan Perkawinan. Pencegahan menurut Kamus Besar Bahasa Indonesia (2018) adalah proses, cara, tindakan mencegah atau tindakan menahan agar sesuatu tidak terjadi. Sesuatu yang dimaksud adalah perkawinan sebagai suatu ikatan lahir batin antara seorang laki-laki dengan seorang wanita agar tidak terjadi atau dilangsungkan. Logika sederhananya, pencegahan tentu dilakukan sebelum terjadinya sesuatu. Apabila perkawinan sudah terjadi, maka UU Perkawinan memungkinkan adanya pembatalan perkawinan.

Perkawinan dapat dicegah jika salah satu pihak tidak memenuhi syarat-syarat untuk melangsungkan perkawinan yang ditentukan Pasal 13 UU Perkawinan. Syarat perkawinan yang tidak dipenuhi misalnya apabila ada pihak yang berada di bawah pengampuan. Untuk melangsungkan perkawinan, disyaratkan seorang pria dan wanita telah berusia 19 (sembilan belas) tahun. Ketentuan umur tersebut dapat disimpangi dengan adanya dispensasi dari Pengadilan yang diajukan orang tua pihak pria dan/atau orang tua pihak wanita yang disyaratkan Pasal 7 UU Perkawinan.

Perkawinan dapat dicegah jika salah satu dari kedua belah pihak terikat perkawinan sebelumnya, kecuali bagi seorang suami yang menginginkan istri lebih dari satu dengan telah melakukan prosedur yang ditentukan Pasal 3 ayat (2) UU Perkawinan. Perkawinan tersebut juga tidak serta merta dapat dilakukan. Ada kondisi tertentu yang harus dipenuhi menurut Pasal 4 ayat (2) UU Perkawinan, yaitu istri tidak dapat menjalankan kewajibannya sebagai istri, istri mendapat cacat badan atau penyakit yang tidak dapat disembuhkan, dan istri tidak dapat melahirkan keturunan. Pencegahan perkawinan diajukan ke Pengadilan tempat perkawinan akan dilangsungkan. Pihak yang dapat mengajukan pencegahan perkawinan adalah para keluarga dalam garis keturunan lurus ke atas dan ke bawah, saudara, wali nikah, wali, pengampu dari salah seorang calon mempelai dan pihak-pihak yang berkepentingan, sebagaimana Pasal 14 juncto Pasal 17 UU Perkawinan. 
Pencegahan perkawinan dapat diajukan apabila perkawinan tersebut belum dilangsungkan. Hal tersebut dapat diketahui ketika membaca Pasal 17 ayat (1) UU Perkawinan yang menentukan pencegahan perkawinan diajukan dimana perkawinan akan dilangsungkan, sehingga sudah sangat jelas bahwa pencegahan harus diajukan sebelum terjadinya perkawinan.

Pembatalan perkawinan diatur dalam Bab IV UU Perkawinan tentang Batalnya Perkawinan. Pembatalan menurut Kamus Besar Bahasa Indonesia (2018) adalah proses, cara, perbuatan membatalkan, pernyataan batal, pembatalan perkawinan diartikan bahwa perkawinan itu sesudah dilangsungkan, namun tidak dipenuhinya sejumlah syarat yang ditentukan oleh peraturan perundangundangan. Menurut Soedaryo Soeimin "pembatalan perkawinan adalah perkawinan yang telah terjadi dengan tanpa memenuhi syarat-syarat sesuai undang-undang" (Marwan dan Mangkupranoto, 1986). Pembatalan perkawinan yaitu tindakan putusan pengadilan yang menyatakan bahwa perkawinan yang dilakukan itu tidak sah, akibatnya perkawinan itu dianggap tidak pernah ada. Soetojo Prawirohamidjojo (2001) pernah mengemukakan bahwa istilah "batalnya perkawinan" tidaklah tepat, tetapi yang lebih tepat adalah "dapat dibatalkannya suatu perkawinan". Bilamana perkawinan itu tidak memenuhi syarat-syarat perkawinan, barulah perkawinan dapat diajukan permohonan pembatalannya di muka pengadilan. Kedua terminologi tersebut (dapat dibatalkan atau vernietigbaar, dan batal atau nietig) memang berbeda pemahamannnya menurut hukum.

Menurut Pasal 22 UU Perkawinan, bahwa perkawinan dapat dibatalkan, apabila para pihak tidak memenuhi syarat-syarat untuk melangsungkan perkawinan. Syarat yang dimaksud diantaranya:

a. Salah satu pihak masih terikat perkawinan sebelumnya, atau

b. Bagi seorang suami yang beristri lebih dari seorang tidak mengajukan permohonan izin ke Pengadilan, atau c. Perkawinan dilangsungkan di hadapan pejabat yang tidak mempunyai wewenang, atau

d. Tanpa wali nikah atau wali nikah yang tidak sah (bagi calon istri)., atau

e. Tanpa dihadiri saksi, atau

f. Perkawinan di bawah ancaman.

Permohonan pembatalan perkawinan diajukan kepada Pengadilan di daerah dimana perkawinan dilangsungkan. Pihak yang dapat mengajukan permohonan pembatalan adalah para keluarga dalam garis keturunan lurus ke atas dari suami atau istri, suami atau istri, pejabat yang berwenang selama perkawinan belum diputuskan, atau pejabat yang ditunjuk Pasal 16 ayat (2) UU Perkawinan, dan setiap orang yang mempunyai kepentingan hukum secara langsung atas perkawinan tersebut.

Perkawinan yang telah dilangsungkan dapat dibatalkan, dan "batalnya perkawinan dimulai setelah putusan Pengadilan yang telah inkracht dan berlaku sejak perkawinan itu dilakukan. Pasal 37 PP 9/1975 menyatakan "Batalnya suatu perkawinan hanya dapat diputuskan oleh pengadilan". Perceraian dan pembatalan perkawinan sama-sama dikategorikan sebagai putusnya perkawinan, dan baru dinyatakan sah menurut hukum negara apabila keluar putusan pengadilan dan dilakukan di muka pengadilan (Lake, 2015). Permohonan pembatalan perkawinan dapat diajukan apabila perkawinan telah dilangsungkan menurut hukum masingmasing agama dan kepercayaan, serta telah dicatatkan.

Kewenangan dan Tanggung Jawab Notaris Yang Membuat Akta Pembatalan Perkawinan

Notaris merupakan pejabat umum yang berwenang untuk membuat akta otentik dan memiliki kewenangan lainnya sebagaimana dimaksud dalam UUJN atau berdasarkan undang-undang lainnya, sebagaimana Pasal 1 angka 1 UUJN. Ketentuan ini menunjukan bahwa notaris adalah seorang Pejabat Umum (Openbaar Ambtenaar) berwenang membuat akta otentik dan memiliki kewenangan lain yang diatur dalam undang-undang ini atau undang-undang lainya (Adjie, 2020). Abdul Ghofur (2009) menyebut bahwa Notaris 
memiliki tugas sebagai pejabat umum dan memiliki wewenang untuk membuat akta otentik. Notaris juga diberikan kewenangan lainnya sesuai dengan yang diatur dalam UUJN.

Kewenangan adalah suatu tindakan hukum yang diatur dan diberikan kepada suatu jabatan berdasarkan peraturan perundangundangan. Hukum Adminitrasi membagi kewenangan atau wewenang menjadi tiga jenis berdasarkan cara perolehannya yaitu atribusi, delegasi atau mandat (Purwaningsih, 2020). Dijelaskan oleh H.D van Wijk/ Willem Konijnenbelt, dikutip dari Ridwan HR (2016), kewenangan atribusi adalah pemberian wewenang pembuat undang-undang kepada organ pemerintahan. Delegasi adalah pelimpahan wewenang dari satu organ pemerintahan kepada organ pemerintahan lainnya dan mandat terjadi ketika organ pemerintahan mengizinkan kewenangannya dijalankan oleh organ lain atas namanya. Notaris sebagai pejabat umum diangkat oleh Menteri Hukum dan Hak Asasi Manusia, sehingga Notaris turut serta melaksanakan tugas-tugas Pemerintah dan turut menjaga kewibawaan Pemerintah melalui perannya dalam membuat akta otentik bagi masyarakat yang memerlukan, termasuk kewenangan atribusi (Soesanto, 1982).

Tugas dan wewenang notaris adalah membuat akta otentik sebatas yang ditentukan oleh peraturan perundang-undangan, sehingga tidak termasuk akta yang dikhususkan dibuat oleh pejabat atau pejabat umum lainnya. Suatu akta dapat disebut sebagai akta otentik jika memenuhi rumusan unsur Pasal 1868 Kitab Undang-Undang Hukum Perdata (selanjutnya disebut KUH Perdata), yakni bentuk akta telah ditentukan oleh undang-undang, dibuat dihadapan pegawai-pegawai umum yang diberi wewenang, di tempat dimana akta itu dibuat. Tidak dipenuhinya salah satu unsur Pasal 1868 KUH Perdata akan mengakibatkan suatu akta tidak dapat disebut sebagai akta otentik.

Sesuai Pasal 15 UUJN, kewenangan notaris membuat akta otentik sebatas yang ditentukan oleh undang-undang, yang dibedakan menjadi kewenangan membuat akta otentik secara umum dan secara khusus (Jozan Adolf, 2020). Terkait dengan kewenangan notaris membuat akta otentik, dijelaskan dalam Pasal 15 ayat (1) UUJN, diantaranya membuat akta otentik mengenai semua perbuatan, perjanjian, dan ketetapan berdasarkan peraturan perundang-undangan atau dikehendaki oleh penghadap agar dinyatakan dalam akta, menjamin kepastian tanggal pembuatan akta, menyimpan akta, memberikan grosse, salinan dan kutipan akta, sepanjang pembuatan akta tersebut tidak dikecualikan kepada pejabat lain yang ditetapkan oleh undang-undang.

Kewenangan khusus notaris diatur dalam Pasal 15 ayat (2) UUJN, diantaranya mengesahkan tanda tangan dan menetapkan tanggal surat di bawah tangan, dan membukukan surat-surat di bawah tangan dengan mendaftarkan semuanya itu dalam buku khusus, membuat kopi dari asli suratsurat di bawah tangan yang berupa Salinan yang memuat uraian sebagaimana ditulis dan digambarkan dalam surat yang bersangkutan, melakukan pengesahan kecocokan fotokopi dengan surat aslinya, dan sebagainya. Notaris juga mempunyai kewenangan khusus sebagaimana yang diatur dalam Pasal 51 UUJN, yaitu untuk membetulkan kesalahan tulis atau kesalahan ketik yang terdapat dalam Minuta akta yang telah ditandatangani, dengan cara membuat Berita Acara Pembetulan dan Salinan atas Berita Acara Pembetulan dan wajib untuk menyampaikannya kepada para pihak.

Bentuk akta otentik telah dirumuskan dalam Pasal 38 UUJN, tersusun secara sistematis dimulai dari awal Akta atau kepala Akta, badan Akta; dan diakhiri dengan akhir akta atau penutup Akta. Awal Akta atau kepala Akta memuat judul Akta; nomor Akta; jam, hari, tanggal, bulan, dan tahun; dan nama lengkap dan tempat kedudukan Notaris. Badan Akta memuat nama lengkap, tempat dan tanggal lahir, kewarganegaraan, pekerjaan, jabatan, kedudukan, tempat tinggal para penghadap dan/atau orang yang mereka wakili; keterangan mengenai kedudukan bertindak penghadap; isi Akta yang merupakan kehendak dan keinginan dari pihak yang 
berkepentingan; dan nama lengkap, tempat dan tanggal lahir, serta pekerjaan, jabatan, kedudukan, dan tempat tinggal dari tiap-tiap saksi pengenal. Akhir atau penutup Akta memuat uraian tentang pembacaan Akta, penandatanganan dan tempat penandatanganan atau penerjemahan Akta jika ada; nama lengkap, tempat dan tanggal lahir, pekerjaan, jabatan, kedudukan, dan tempat tinggal dari tiap-tiap saksi Akta; dan uraian tentang tidak adanya perubahan yang terjadi dalam pembuatan Akta atau uraian tentang adanya perubahan yang dapat berupa penambahan, pencoretan, atau penggantian serta jumlah perubahannya.

Suatu akta baru bisa menjadi akta otentik jika memenuhi syarat yang telah ditentukan undang-undang. Seorang notaris dalam melaksanakan tugasnya wajib melaksanakan tugasnya dengan penuh disiplin, profesional, dan integritas moralnya tidak boleh diragukan. Apa yang tertuang dalam awal dan akhir akta yang menjadi tanggung jawab notaris adalah ungkapan yang mencerminkan keadaan yang sebenarbenarnya pada saat pembuatan akta (Tan Thong Kie, 2000). Ghofur (2009) mengemukakan bahwa mengenai tanggung jawab notaris sehubungan dengan kebenaran materiil terhadap akta yang dibuatnya dapat dibedakan menjadi empat poin, yakni:

1. Tanggung jawab notaris secara perdata terhadap kebenaran materiil atas akta yang dibuatnya;

2. Tanggung jawab notaris secara pidana terhadap kebenaran materiil dalam akta yang dibuatnya;

3. Tanggung jawab notaris berdasarkan peraturan jabatan notaris (UUJN) terhadap kebenaran materiil dalam akta yang dibuatnya;

4. Tanggung jawab notaris dalam menjalankan tugas jabatannya berdasarkan kode etik notaris.

Apabila dikaitkan dengan teori tanggung jawab, pertanggung jawaban yang dilakukan oleh Notaris merupakan akibat dari pelaksanaan tugas dan jabatannya. Oleh karena itu, tanggung jawab yang digunakan dalam UUJN adalah tanggung jawab berdasarkan kesalahan. Notaris dapat dimintakan pertanggung jawaban atas pelanggaran yang dilakukannya karena sengaja melakukan perbuatan tersebut dan menimbulkan kerugian bagi para pihak.

Spesifik mengenai akta yang dibuat di hadapan notaris yang berjudul Pembatalan Perkawinan, terjadi dalam kasus perkawinan antara X dan Y, sama-sama beragama Hindu dan telah dilangsungkan menurut hukum agama (Hindu) di hadapan pemuka agama. Ketika calon istri akan mencatatkan perkawinannya di Kantor Dinas Kependudukan dan Catatan Sipil Kota Mataram, ternyata ditolak dengan alasan $\mathrm{X}$ telah membatalkan perkawinannya dengan membuat akta di hadapan notaris.

Pembatalan perkawinan sebagaimana telah diuraikan di atas berarti perkawinan telah dilangsungkan menurut hukum agama dan atau kepercayaannya, dan telah dicatatkan sesuai dengan ketentuan Pasal 2 UU Perkawinan, karena tidak dipenuhinya syarat perkawinan sebagaimana disyaratkan Pasal 22 UU Perkawinan. Pihak yang berhak membatalkan perkawinan diantaranya adalah suami atau istri, dan pembatalan diajukan ke Pengadilan tempat di mana perkawinan tersebut dilangsungkan (vide Pasal 23 juncto Pasal 25 UU Perkawinan).

Sementara dalam kasus a quo, perkawinan belum dilaksanakan karena belum dicatatkan, sehingga yang seharusnya dilakukan adalah pencegahan perkawinan yang dimaksud dalam Pasal 13 UU Perkawinan. Pembatalan atau pencegahan perkawinan dibuktikan dengan adanya penetapan perkawinan dari Pengadilan Negeri (perkawinan tidak didasarkan hukum agama Islam) dimana perkawinan tersebut akan dilangsungkan. Dikaitkan dengan kewenangan notaris membuat akta otentik, yakni akta yang bersifat umum sebagaimana Pasal 15 ayat (1) UUJN dan akta yang bersifat khusus sebagaimana Pasal 15 ayat (2) UUJN, notaris jelas tidak mempunyai kewenangan membuat akta pembatalan perkawinan.

Pembatalan perkawinan termasuk kewenangan pejabat lain sebagaimana dimaksud oleh Pasal 15 ayat (1) UUJN. 
Notaris bukan merupakan pejabat yang berwenang membuat akta dimaksud. Akta pembatalan perkawinan yang dibuat oleh pejabat yang tidak mempunyai kewenangan tidak akan memiliki kekuatan hukum. Seharusnya Kantor Dinas Kependudukan Dan Catatan Sipil Kota Mataram tetap mencatat perkawinan tersebut. Penolakan pencatatan perkawinan tersebut menjadikan calon istri menderita kerugian, baik materiil yang dapat dihitung jumlahnya berupa pengeluaran biaya perkawinan yang dilangsungkan menurut hukum agamanya, maupun kerugian immateriil berupa rasa malu perkawinan yang telah disahkan oleh Pemuka agama, tetapi dibatalkan secara sepihak.

Notaris dalam menjalankan jabatannya wajib melaksanakan tugasnya dengan penuh disiplin dan integritas moralnya tidak boleh diragukan. Jika seorang notaris membuat akta padahal pembuatan akta tersebut merupakan kewenangan pejabat lain, maka notaris tersebut menurut teori tanggung jawab, yang mengetahui bahwa pembatalan perkawinan merupakan wewenang pejabat lain, seharusnya menolak untuk membuat akta pembatalan perkawinan. Notaris dapat dimintakan pertanggung jawaban atas pelanggaran tersebut karena kelalaiannya melakukan perbuatan tersebut dan menimbulkan kerugian bagi para pihak.

Y sebagai calon istri yang menderita kerugian akibat penolakan pencatatan perkawinan oleh Kantor Dinas Kependudukan Dan Catatan Sipil Kota Mataram tersebut dapat meminta pertanggung jawaban terhadap notaris yang bersangkutan secara perdata mengenai kebenaran formil terhadap akta yang dibuatnya karena telah melakukan perbuatan melanggar hukum (onrechtmatige daad) berupa pelanggaran Pasal 15 UUJN. Pasal 1365 KUH Perdata mengatur bahwa Y dapat meminta penggantian biaya, rugi dan bunga secara materiil maupun secara immateriil kepada notaris yang bersangkutan.

\section{KESIMPULAN}

Akta Pembatalan Perkawinan Nomor 1

Tanggal 22 Juli 2017 yang dibuat di hadapan notaris tidak mempunyai kekuatan mengikat, karena notaris tidak mempunyai wewenang membuat akta pembatalan perkawinan. Pembuatan akta tersebut menjadi wewenang pejabat lain sesuai dengan yang dimaksud ketentuan Pasal 15 UUJN.

Dibuatnya akta pembatalan perkawinan tersebut menjadikan $\mathrm{Y}$ sebagai calon istri yang permohonan pencatatan perkawinannya ditolak, menderita kerugian baik materiil maupun immateriil. Atas kerugian tersebut, notaris dapat dimintakan pertanggung jawaban secara perdata karena telah melakukan perbuatan melanggar hukum sebagaimana dimaksud Pasal 15 UUJN juncto Pasal 1365 KUH Perdata.

\section{SARAN}

Hendaknya Majelis Pengawas Daerah Notaris memberikan sanksi kepada notaris yang membuat akta yang berada di luar kewenangannya, khususnya akta pembatalan perkawinan, dengan dasar melampaui kewenangannya sebagai pejabat umum yang mempunyai wewenang membuat akta otentik. Pihak yang dirugikan akibat tindakan notaris dimaksud agar dapat mengajukan gugatan ganti kerugian agar tidak ada lagi kesalahan yang dilakukan notaris di kemudian hari. Dinas Kependudukan dan Catatan Sipil, diharapkan lebih dapat memahami UU Perkawinan secara komprehensif agar tidak ada kekeliruan dalam melaksanakan tugas dan kewajibannya. Pemerintah di tingkat pusat maupun daerah diharapkan dapat memberikan penyuluhan dan sosialisasi secara berkala dan menyeluruh mengenai peraturan perundang-undangan terkait kepada dinas atau instansi-instansi terkait.

\section{UCAPAN TERIMA KASIH}

Disampaikan terima kasih kepada pihak Fakultas Hukum Universitas Surabaya yang telah memberikan kesempatan kepada penulis untuk menempuh Pendidikan magister sampai dapat menelurkan penelitian ini. Apresiasi juga disampaikan teruntuk pihakpihak yang secara langsung atau tidak langsung mendukung terlaksananya penelitian ini. 


\section{DAFTAR PUSTAKA}

Adjie, Habib. 2020. Jurnal Notarius. Vol. XIII,

No. 1. Universitas Diponegoro.

Adolf, Jozan, et. al. 2020. Jurnal Notarius. Vol. XIII, No. 1. Universitas Diponegoro.

Anshori, Abdul Ghofur. 2009. Lembaga Kenotariatan Indonesia. Yogyakarta: UI Press.

Fitria, Reza. Jurnal Privat Law. Vol. III No 2 Juli-Desember 2015.

HR, Ridwan. 2016. Hukum Administrasi Negara. Jakarta: Rajawali Pers.

Kementerian Pendidikan dan Kebudayaan. (2018). Kamus Besar Bahasa Indonesia. Jakarta: Balai Pustaka.

Kie, Tan Thong. 2000. Studi Notariat-Serba Serbi Praktek Notaris. Jakarta: Ichtiar Baru Van Hoeve.

Lake, Inggrid Maria. 2015. Putusnya Perkawinan Karena Pembatalan Perkawinan, Tesis, Program Studi Magister Kenotariatan Fakultas Hukum Universitas Airlangga, Surabaya.

Marwan, Muchlis, Mangkupranoto, Thoyib. 1986. Hukum Islam II, Surabaya: Buana Cipta.

Marzuki, Peter Mahmud. 2009. Penelitian Hukum. Jakarta: Kencana Prenada Media Group.

Prawirohamidjojo, R. Soetojo. 2001. Pluralisme Dalam Undang-undang Perkawinan Di Indonesia. Surabaya: Airlangga University Press.

Saleh, K. Wantjik. 1976. Hukum Perkawinan Indonesia. Jakarta: Ghalia Indoensia.

Soesanto, R. 1982. Tugas, Kewajiban dan Hak-Hak Notaris, Wakil Notaris. Jakarta: Pradnya Paramita.

Munawar. Akhmad. 2015. Jurnal Al' Adl. Volume VII Nomor 13.

Purwaningsih. 2020. Jurnal Notarius, Volume XIII Nomor 1.

Putusan Mahkamah Konstitusi Nomor 46/PUU-VIII/2010. 